\title{
Reseña
}

\author{
Review
}

\section{Alberto José Campillo Pardo. Censura, expurgo y control en la bi- blioteca colonial neogranadina. Bogotá: Universidad del Rosario. 2017. 142 pp.}

\author{
Clara Isabel Hernández \\ Universidad del Valle \\ claraisabel1028@hotmail.com
}

Fecha de recepción: 10 de agosto de 2018

Fecha de aprobación: 18 de diciembre de 2018

La historia del libro y las bibliotecas ha venido postulándose como un nuevo campo de investigación en el que hoy recaen importantes objetos de estudio que pretenden entender problemáticas históricas que van desde la circulación de los libros, hasta la manera en que se transmitían las ideas a través de la imprenta y su consecuente aplicación en el imaginario de la sociedad. En la historiografía colombiana éste tipo de trabajos comienza a ser una apuesta investigativa que plantea nuevos retos y posibilidades, pero al mismo tiempo tiende a ser una forma de entender los libros como vehículos de circulación de conocimientos y de ideas.

En esta ocasión el politólogo y magíster en historia de la Universidad de los Andes, Alberto José Campillo Pardo, ha elaborado un completo estudio sobre la censura en las bibliotecas coloniales que ha plasmado en su libro Censura, expurgo y control en la biblioteca colonial neogranadina. Allí, se ha concentrado en explicar cómo funcionó el proceso de censura ejecutado por parte de la Inquisición en los libros que pertenecieron a la Biblioteca Antigua del Colegio Mayor del Rosario y a la biblioteca de los jesuitas antes de su expulsión, los cuales reposan actualmente en la colección de libros antiguos de la Biblioteca Nacional de Colombia.

El autor busca, también, dar un punto de vista innovador acerca de lo que para él fue la Inquisición en relación con la censura de libros, en tanto que propone desmitificarla. Así, para Alberto Campillo, la Inquisición estuvo ligada al proceso de ordenamiento social colonial que si bien en un principio reprimía, también buscaba mantener un statu quo promovido por la iglesia católica y la corona española, por medio del cual se proponían librar a la sociedad de ideas heréticas que pudieran significar un cambio en la forma de vida de las personas. 
El autor divide su libro en tres capítulos. En el primero de ellos, titulado Censura, control y legitimación, muestra la censura como un elemento positivo que tenía la facultad de crear un espíritu en la sociedad colonial, también como un instrumento legitimador de la circulación del conocimiento. Éste capítulo está dividido en cuatro apartados: en ellos se aborda el origen de la censura en los libros, las diversas tipologías que existen de ella y sobretodo el marco legal que existió para regular la circulación de los mismos.

Es decir, con dichas tipologías se puede entender si un libro era sometido a una censura previa, por medio de la cual los censores determinaban si debía ser impreso, o si se trataba de una censura de tipo postimpresión representada en las protestas de la ortodoxia, las cuales dejaban a disposición de la iglesia el proceso de revisión del contenido de un libro. En el apartado sobre las censuras impresas, que era un híbrido entre los dos tipos mencionados anteriormente, se muestra cómo se pretendía incluir en los libros reeditados advertencias en las cuales se especificaba que un libro ya había sido censurado y por tanto que estaba libre de ideas prohibidas.

En otro de los apartados titulado La normatividad y la censura positiva, el autor toma la teoría de Michael Foucault para explicar cómo el "poder creador" es un fenómeno que afectaba el ámbito jurídico del conocimiento. De allí que Alberto Campillo muestre todo el entramado de leyes que regulaban la circulación de los libros, como por ejemplo, las Leyes de Indias, la inspección de librerías y bibliotecas, así como también los controles sobre los impresores y los índices expedidos por la Santa Inquisición que a lo largo de los siglos XVI, XVII y XVIII fueron configurando los listados de libros prohibidos. Sumado a lo anterior, el autor realiza una clasificación a dichos índices, lo cual le permite demostrar que la circulación de los libros estaba sujeta a las ordenanzas de lo que en estos se había dispuesto ejercer la labor de la censura.

Teniendo en cuenta lo anterior, desde mi punto de vista la innovación en la investigación que realizó Alberto Campillo está resumida en plantear la normatividad de la censura y el expurgo de los libros con un carácter positivo sin que por ello lo represivo desaparezca. Esto es tratar de entender el hecho de que la iglesia vea en la imprenta un instrumento de difusión del conocimiento útil (muy bien diferenciado entre lo que eran los conocimientos mágicos y los de la naturaleza), al que apoya desde el punto de vista de un artefacto que se presenta como un don de Dios, pero al que se le debe controlar el funcionamiento para evitar la difusión de ideas consideradas en la época como heréticas y que, por tanto, podían alterar las actuaciones o la moral de la sociedad colonial.

En un segundo capítulo, el libro hace referencia al carácter represivo de la censura y cómo la normatividad se va a ver reflejada en las bibliotecas coloniales de la Nueva Granada. Para ello, Alberto Campillo, realiza en el primer apartado una relación entre la censura y la reforma que fue para la iglesia y la monarquía hispánica una especie de amenaza, lo que significó a su vez un mayor control sobre los libros 
de autores protestantes. En un segundo momento, el autor se detiene en las normas censoras explicando por medio de ejemplos con imágenes de libros censurados, cómo los índices, edictos y bulas constituyeron todo un entramado de legitimación del conocimiento. En el último apartado dedicado a los censores busca dar respuesta a la pregunta sobre quiénes eran ellos y cuáles eran los requisitos que debían cumplir para acceder a tal condición.

En el tercer y último capítulo la obra hace relación al expurgo, de tal modo que el autor intenta ver el verdadero alcance de la censura en las fuentes que ha consultado. Por ende, él va a mostrar qué tipo de normas expurgatorias fueron más usadas y cuáles no. En efecto, ello le permite llegar a conclusiones importantes que están directamente relacionadas con la circulación de las ideas, por ejemplo, se presenta el hecho de que entre los tipos de censura más comunes estaban los menos represivos y por tanto, los más laxos o permisivos, cuestiones de las que se sirve el autor para poner en cuestionamiento la efectividad de la censura y la rigurosidad en la prohibición de los libros.

En este sentido, las anotaciones expurgatorias, los tachones, las marcas o señalamientos y las páginas arrancadas o pegadas van ser fenómenos que tienen presencia en las bibliotecas coloniales, unas en mayor medida que otras, pero al fin y al cabo medidas que permiten saber quiénes eran los censores, por qué censuraban una obra, cómo lo hacían y cuando las anotaciones dan cabida al lugar, poder hacerse a una idea de las rutas de circulación de los libros; de esta manera el autor está dejando abierta la temática investigativa en cuanto a la historia del libro se refiere.

En este orden de ideas, el libro de Alberto Campillo es una investigación que se sale de los cánones establecidos hasta ahora, en los que se critica a la inquisición como una institución represiva y no se da cabida a otras perspectivas. Considero que esta obra es una fascinante invitación para adentrarse en el mundo del libro en la época colonial neogranadina, pero también para mirar "las dos caras" de la censura.

Con todo, es importante destacar el hecho de que unida a la teoría del "control legitimador" tomada de Michael Foucault, están las imágenes (en este caso fotografías) que permiten ver los casos de censura y le permiten al lector acercarse de algún modo a la materialidad del libro, además de ser una metodología que se acerca a la imagen como un recurso de primera mano en la investigación histórica.

Sólo quisiera hacer el reparo de que el autor menciona en la introducción que incluirá en su estudio a la ciudad de Popayán, pero sólo lo hace para mencionar a unos censores y para decir brevemente que allí también hubo casos de represión contra las ideas dada su importancia en la época colonial como uno de los principales enclaves de comercio, pero no se observa en la obra ningún caso en el que se observe algún tipo de censura en un libro determinado de una biblioteca payanesa. Por lo demás, considero que este es uno de los trabajos pioneros que hacían falta en la historiografía colombiana. 